\title{
Article \\ Using Waste Sulfur from Biogas Production in Combination with Nitrogen Fertilization of Maize (Zea mays L.) by Foliar Application
}

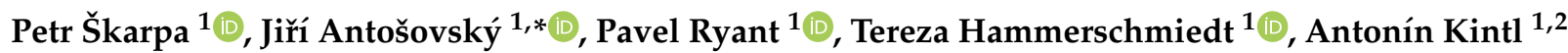 \\ and Martin Brtnický ${ }^{1}$ (D) \\ 1 Department of Agrochemistry, Soil Science, Microbiology and Plant Nutrition, Mendel University in Brno, \\ Zemědělská 1, 61300 Brno, Czech Republic; petr.skarpa@mendelu.cz (P.Š.); pavel.ryant@mendelu.cz (P.R.); \\ tereza.hammerschmiedt@mendelu.cz (T.H.); antonin.kintl@mendelu.cz (A.K.); \\ martin.brtnicky@mendelu.cz (M.B.) \\ 2 Agricultural Research, Ltd., Zahradní 400/1, 66441 Troubsko, Czech Republic \\ * Correspondence: jiri.antosovsky@mendelu.cz; Tel.: +420-545-133-093
}

Citation: Škarpa, P.; Antošovský, J.; Ryant, P.; Hammerschmiedt, T.; Kintl, A.; Brtnický, M. Using Waste Sulfur from Biogas Production in Combination with Nitrogen Fertilization of Maize (Zea mays L.) by Foliar Application. Plants 2021, 10, 2188. https://doi.org/10.3390/ plants10102188

\section{Academic Editors:}

Przemysław Barłóg, Jim Moir, Lukas Hlisnikovsky and Xinhua He

Received: 19 September 2021

Accepted: 13 October 2021

Published: 15 October 2021

Publisher's Note: MDPI stays neutral with regard to jurisdictional claims in published maps and institutional affiliations.

Copyright: (c) 2021 by the authors. Licensee MDPI, Basel, Switzerland. This article is an open access article distributed under the terms and conditions of the Creative Commons Attribution (CC BY) license (https:// creativecommons.org/licenses/by/ $4.0 /)$.

\begin{abstract}
In Europe, mainly due to industrial desulfurization, the supply of soil sulfur (S), an essential nutrient for crops, has been declining. One of the currently promoted sources of renewable energy is biogas production, which produces $S$ as a waste product. In order to confirm the effect of the foliar application of waste elemental $S$ in combination with liquid urea ammonium nitrate (UAN) fertilizer, a vegetation experiment was conducted with maize as the main crop grown for biogas production. The following treatments were included in the experiment: 1. Control (no fertilization), 2. UAN, 3. UANS1 (N:S ratio, 2:1), 4. UANS2 (1:1), 5. UANS3 (1:2). The application of UAN increased the $\mathrm{N}$ content in the plant and significantly affected the chlorophyll content ( $\mathrm{N}$-tester value). Despite the lower increase in nitrogen $(\mathrm{N})$ content and uptake by the plant due to the application of UANS, these combinations had a significant effect on the quantum yield of PSII. The application of UANS significantly increased the $S$ content of the plant. The increase in the weight of plants found on the treatment fertilized with UANS can be explained by the synergistic relationship between N and S, which contributed to the increase in crop nitrogen use efficiency. This study suggests that the foliar application of waste elemental S in combination with UAN at a 1:1 ratio could be an effective way to optimize the nutritional status of maize while reducing mineral fertilizer consumption.
\end{abstract}

Keywords: chlorophyll content; fluorescence parameters; plant weight; plant nutrient content; nitrogen use efficiency

\section{Introduction}

One of the principles of the European Green Deal is the proposal of greenhouse gas emissions cut by at least $55 \%$ by the year 2030, which should set Europe to a path to becoming climate-neutral by the year 2050 [1]. According to the European Biogas Association (EBA), biogas, biomethane, and other renewable gases will play a key role in helping Europe's transition to a clean energy system [2], and the European Commission's strategies promise targeted support for biogas in the revised Renewable Energy Directive and gas legislation. EBA, Eurogas, and the Gas for Climate consortium are calling for an EU-wide renewable target of at least $11 \%$. The annual production of biogas in Europe reaches $15.8 \mathrm{bcm}$ and is relatively stable with a total of 18,943 biogas plants according to the EBA [3].

A biogas plant produces biogas, which can then be used for the cogeneration of electricity and heat. Biogas is a mixture of methane, carbon dioxide, and other components such as hydrogen sulfide $\left(\mathrm{H}_{2} \mathrm{~S}\right)$ [4]. The biogas must be pretreated before use. The first step of the purification process is the removal of $\mathrm{H}_{2} \mathrm{~S}$, which is corrosive and harmful to 
health $[5,6]$. Biogas production is thus associated with the production of waste products. The utilization of waste sulfur obtained from the purification process seems to be promising from the point of view of plant nutrition and especially from the economic aspect of biogas production $[7,8]$ and sulfur deficiency in the environment.

European $\mathrm{SO}_{2}$ emissions have been reduced by $70-80 \%$ since $1990[9,10]$. According to results of Engardt et al. [11], sulfur deposition in Europe will decrease until, at least, 2050. For example, in the Czech Republic, atmospheric sulfur deposition is about $5 \mathrm{~kg} / \mathrm{ha}$ per year [12], so there is a shortage of sulfur in the soil, as it has been presented by many authors [13-18]. According to Zbíral et al. [19], a statistically highly significant decrease in the soil $\mathrm{S}$ content caused by reduction of $\mathrm{SO}_{2}$ emissions in the long-term field experiments in Czech Republic from $33 \mathrm{mg} / \mathrm{kg}$ in 1981 to $8 \mathrm{mg} / \mathrm{kg}$ in 2017. Therefore, it is necessary to pay special attention to fertilization by sulfur in addition to the other essential nutrients, especially because of the increased cultivation of crops with high sulfur requirements $[19,20]$. Sulfur in plants is essential for the synthesis of cysteine, methionine, and some vitamins [21]. The deficiency of sulfur in maize as the main crop for biogas production not only reduces yield but also quality parameters such as the content of starch, carbohydrates, and proteins [22]. Sulfur is usually applied in the form of mineral fertilizers, and co-application with nitrogen is recommended by many authors as these nutrients have been proven to have good synergy [23,24]. Salvagiotti and Miralles [25] showed that $\mathrm{S}$ addition increased the biomass and grain yield of cereal and the positive interaction of $\mathrm{N}$ and $\mathrm{S}$, which resulted in a greater nitrogen use efficiency. A shortage of S supply also lowers the utilization of nitrogen and results in a deterioration in crop quality [26]. As sulfur is an essential constituent of enzymes involved in nitrogen metabolism, its deficiency could lead to a decrease in $\mathrm{N}$ assimilation $[27,28]$. Some reports have shown the accumulation of nitrates in S-deficient plants [29]. In addition, Haneklaus et al. [30] reported that each $\mathrm{kg}$ of $S$ deficit causes $15 \mathrm{~kg}$ of nitrogen to be lost in the environment. Maize is an important crop that, despite its relatively low sulfur requirements, is severely affected by its deficiency [31,32].

Nitrogen is essential for plants in terms of biomass and yield production [33]. In addition to the conventional nitrogen fertilization of the soil, the nutritional status of the plants can be optimized by foliar fertilization during the plant growth [34]. Foliar fertilization could be used under farming conditions as a quick correction for unexpected nutrient deficiencies, for the late supply of $\mathrm{N}$ (and another nutrients) during advanced growth stages, and as a preventive measure against unsuspected (or hidden) deficiencies [35-38]. The foliar application of nutrients is also recommended when the soil or the plant conditions limit the availability of some nutrients [39] and is appropriate under conditions when high loss rates of soil-applied nutrients may occur [40]. For example, the foliar application of nitrogen has significantly improved the grain yield of maize [41] and other cereal crops [42].

The aim of this study was to verify the effect of the foliar application of waste elemental sulfur from biogas production in combination with conventional liquid fertilizers UAN applied in different ratios. Such a reutilization of waste sulfur from biogas plants back in agriculture is suitable from the economic aspect of biogas purification and waste management. The application of this sulfur could help to reduce the consumption of mineral fertilizers and, at the same time, address the deficient sulfur content in the soil and plants.

\section{Results and Discussion}

The application of UAN fertilizer alone and in combination with sulfur increased the chlorophyll content ( $\mathrm{N}$-tester value) in maize leaves compared to the unfertilized control. The increase in chlorophyll was evident at both monitoring terms (t1 and t2), while the differences between the control (N-unfertilized treatment) and the N (UAN) and NS (UANS1-3)-fertilized treatments increased over time (Table 1). 
Table 1. The effect of the foliar fertilizer application on chlorophyll contents ( $\mathrm{N}$-tester value).

\begin{tabular}{ccccc}
\hline \multirow{2}{*}{ Treatment } & \multicolumn{2}{c}{ t1 } & \multicolumn{2}{c}{ t2 } \\
\cline { 2 - 5 } & N-Tester Value & Rel. $\%$ & N-Tester Value & Rel. \% \\
\hline Control & $271 \pm 5^{\mathrm{f}}$ & 100.0 & $196 \pm 12^{\mathrm{g}}$ & 100.0 \\
UAN & $465 \pm 11^{\mathrm{a}}$ & 171.6 & $379 \pm 13^{\mathrm{cd}}$ & 193.4 \\
UANS1 & $397 \pm 14^{\mathrm{bc}}$ & 146.5 & $349 \pm 28^{\mathrm{de}}$ & 178.0 \\
UANS2 & $414 \pm 11^{\mathrm{b}}$ & 152.8 & $325 \pm 12^{\mathrm{e}}$ & 165.8 \\
UANS3 & $393 \pm 12^{\mathrm{bc}}$ & 145.0 & $319 \pm 13^{\mathrm{e}}$ & 162.8 \\
\hline
\end{tabular}

The values in the table represent the arithmetic mean $(n=8) \pm \mathrm{SD}$ (standard deviation). The same letters next to the numbers describe no statistically significant differences between the treatments (Fisher's LSD test, $p<0.05$ ). The relative expression of the values is shown in the column marked Rel. \% (Control $=100 \%$ ). The measurements were performed at two growth stages, $\mathrm{t} 1$ (5th true leaf) and $\mathrm{t} 2$ (6th true leaf).

The $\mathrm{N}$-tester values were significantly correlated with the rate of nitrogen applied in fertilizers at both terms, as presented in Figure 1. The results agree with several studies that have reported a strong correlation between chlorophyll content and the amount of nitrogen in leaves [43-47].

t1

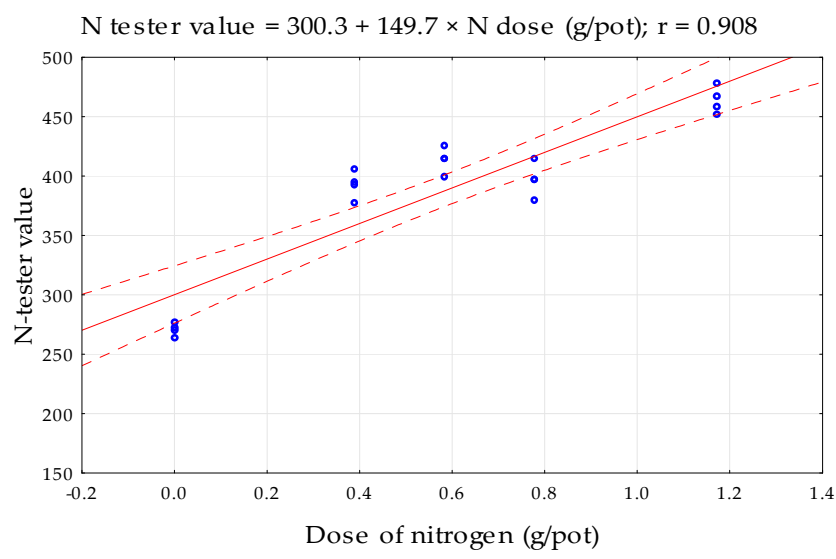

t2

$\mathrm{N}$ tester value $=226.4+148.2 \times \mathrm{N}$ dose $(\mathrm{g} / \mathrm{pot}) ; \mathrm{r}=0.903$

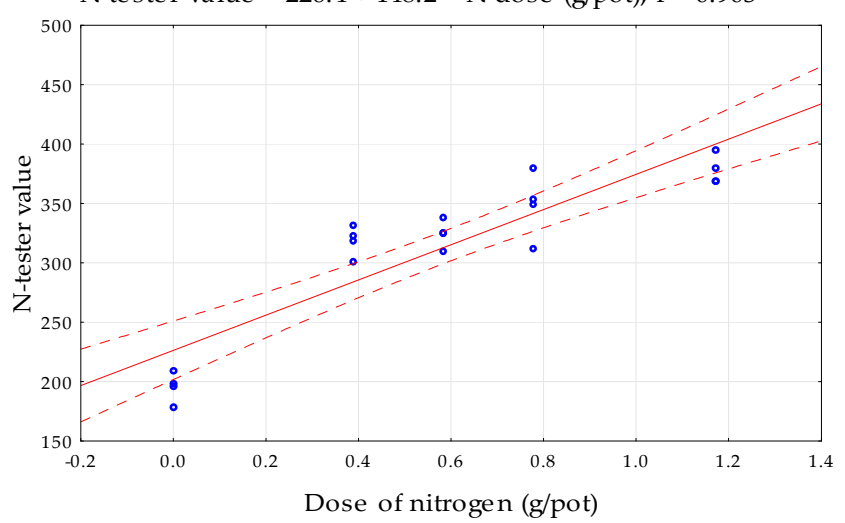

Figure 1. Dependence of N-tester value on nitrogen dose. The measurements were carried out on the 1st (t1) and 2nd (t2) growth stages of maize.

Nitrogen is part of the enzymes associated with chlorophyll synthesis [48] and the chlorophyll concentration reflects relative crop $\mathrm{N}$ status. Statistically significant highest $\mathrm{N}$-tester values were found for the treatment fertilized with UAN applied without sulfur (UAN) on both measurement terms ( $\mathrm{t} 1 ; \mathrm{t} 2)$. The highest nitrogen dose was applied on this treatment. The application of UAN in combination with elemental sulfur (UANS1-3) significantly increased the $\mathrm{N}$-tester value compared to the unfertilized (control) treatment, but the level of chlorophyll content did not reach the values found in plants fertilized with UAN alone. While, in the first measurement term (t1), the highest $\mathrm{N}$-tester value was found for the UANS2 treatment (Table 1), in term t2, the N-tester values were in direct dependence on the nitrogen doses contained in the UAN-sulfur mixture. The $\mathrm{N}$-tester values found at both terms $(\mathrm{t} 1 ; \mathrm{t} 2)$ were significantly correlated with the plant nitrogen content detected at term $\mathrm{t} 3(\mathrm{r}=0.711, p<0.001 ; \mathrm{r}=0.707, p<0.001$, respectively). Evaluation of the nutritional status after the joint application of nitrogen and sulfur using the N-tester was also performed on several dates by Lacroux et al. [49], and their results showed a significant increase in measured values compared to the control, with the highest values achieved by the joint foliar application of $\mathrm{N}$ and $\mathrm{S}$.

The ability of the photosystem II to absorb radiation is expressed by the variable chlorophyll fluorescence for dark-adapted leaves $\left(F_{v}\right)$. The more radiation a plant can absorb, the more radiation the plant can use for photosynthesis. Although the ability of 
the plant tissue to absorb radiation decreased over time (comparison of $F_{v}$ levels between $\mathrm{t} 1$ and $\mathrm{t} 2$ ), this decrease was not significant for the UAN and UAN combination with sulfur. A significant reduction in $F_{v}$ values was only observed in the unfertilized treatment (Figure 2). Even though the treatment with the highest sulfur dose (UANS3) showed the lowest $F_{v}$ values, the results showed that the decrease in $F_{v}$ between terms $\mathrm{t} 1$ and $\mathrm{t} 2$ was smallest on this treatment. Nitrogen deficiency decreases the photosynthetic assimilation capacity of $\mathrm{CO}_{2}$ of plant leaves, leading to decreases in light-saturated photosynthetic rates [50]. In addition, Ciompi et al. [51] and Jin et al. [52] reported a positive correlation between the nitrogen content in the plant tissue of leaves and photosynthetic capacity.

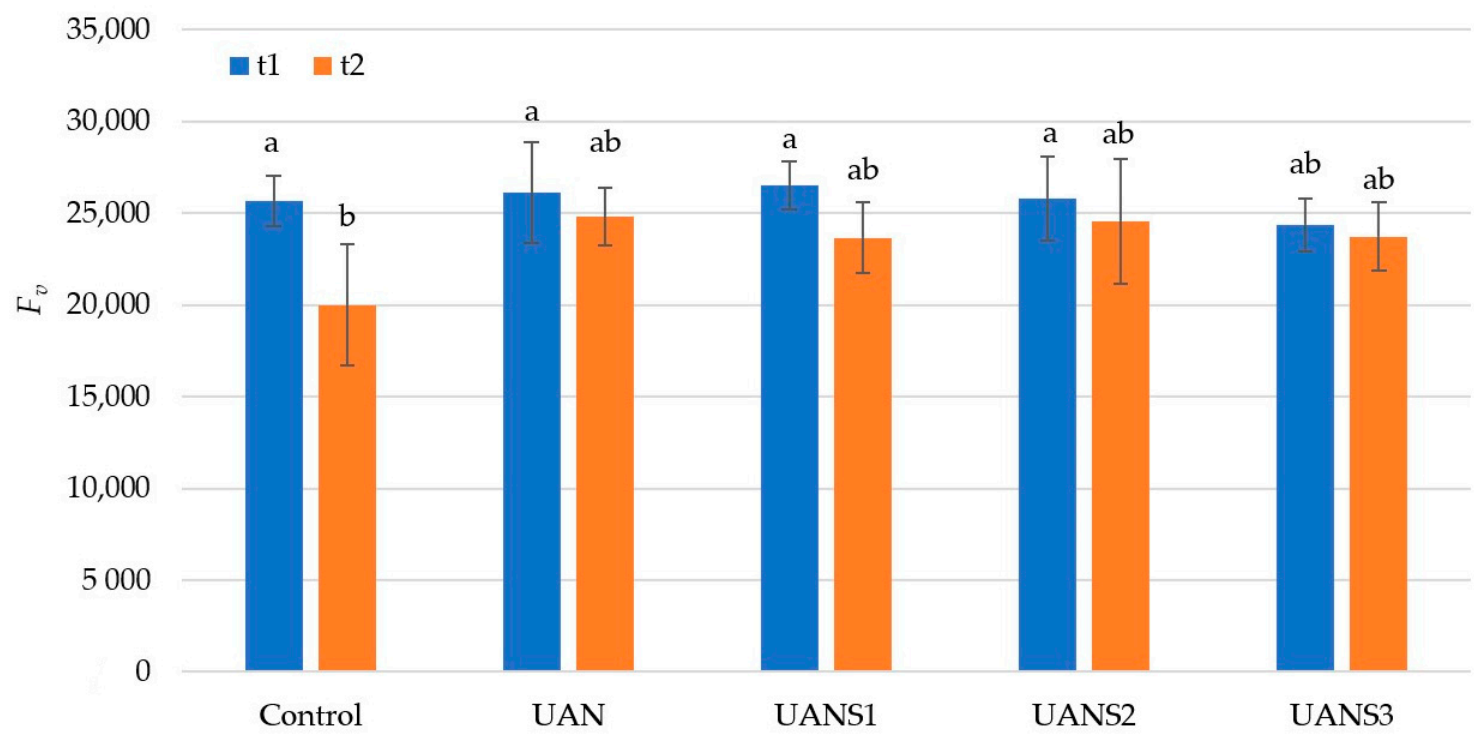

Figure 2. Variable fluorescence $\left(F_{v}\right)$ value after the foliar application of fertilizers. The measurements were carried out on two growth stages of maize ( $\mathrm{t} 1$ and $\mathrm{t} 2)$. The values represent the arithmetic mean $(n=8)$; the bars represent the standard deviation of the mean. There are no statistical differences between columns with the same letters (Fisher's LSD test, $p<0.05$ ).

After dark adaptation of the maize leaves, the maximum photosynthetic capacity $\left(\Phi_{P S I I}\right)$ was estimated as the quotient between variable and maximum fluorescence $\left(F_{v} / F_{m}\right)$. The quantum yield, which indicates the actual capacity for photochemical processes by the availability of reaction centers of the photosystem II (PSII), was significantly $(p \leq 0.05)$ influenced by the fertilizer application (Figure 3). It is clear that nitrogen significantly affects photosynthesis and chlorophyll fluorescence of the plant. This was demonstrated by the response of maize to nitrogen fertilization in a study by Ahmad et al. [53], in which the effect of nitrogen application increased the electron transport rate, photochemical quenching coefficient, variable fluorescence, maximal quantum yield, and effective quantum yield of PSII photochemistry. A significant increase in $\Phi_{P S I I}$ values in three maize varieties due to a high nitrogen dose was demonstrated by Jin et al. [52]. Reductions in the quantum yield of PSII electron transfer due to nitrogen deficiency were also described by Nunes et al. [54] and Verhoeven et al. [55]. In our study, the values of $\Phi_{P S I I}$ were decreased over time regardless of fertilization treatment. The highest value of $\Phi_{P S I I}$ was determined after the application of UAN with the highest elemental sulfur content (UANS3). These results contradict the above studies, but, on the other hand, they show a positive effect of applied sulfur on nitrogen utilization and its use by the plant. A high linear dependence between the efficiency of carbon fixation and quantum yield value was presented by Fryer et al. [56].

The rate of fluorescence decline $\left(R_{F d}\right)$, an empirical parameter for the quantification of plant vitality under tested conditions, was measured. In contrast to the values of the variable chlorophyll fluorescence $\left(F_{v}\right)$ and quantum yield of PSII $\left(\Phi_{P S I I}\right)$, the rate of fluorescence decline was not statistically significantly affected by foliar fertilization. Only at term $\mathrm{t} 2$ did the $R_{F d}$ value of plants grown on the UANS2 treatment decrease significantly 
below the control level, but no trend in the decrease in $R_{F d}$ due to UAN fertilization in combination with elemental sulfur was observed (Figure 4).

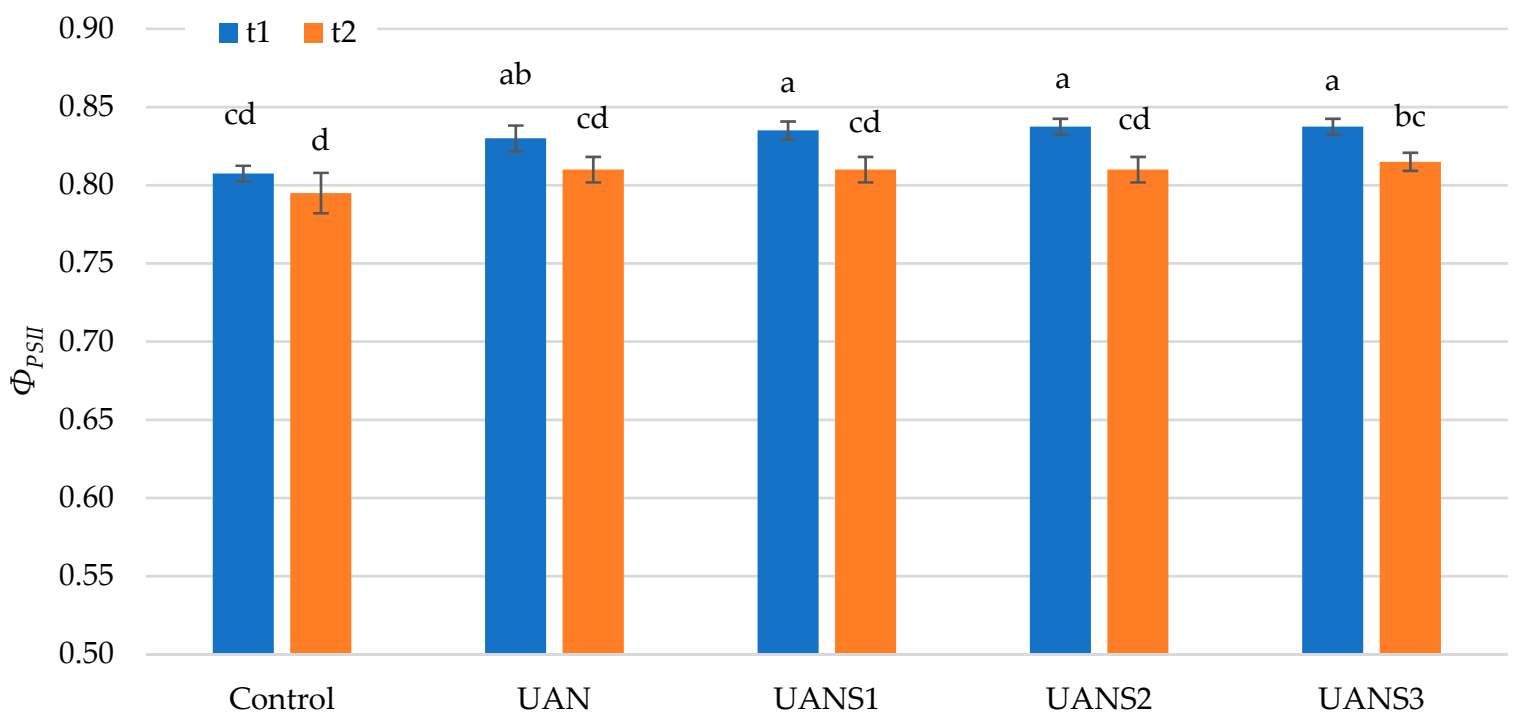

Figure 3. The effect of the foliar application of fertilizers on the quantum yield of PSII photochemistry $\left(\Phi_{P S I I}\right)$. The measurements were carried out on two growth stages of maize ( $\mathrm{t} 1$ and $\mathrm{t} 2)$. The values represent the arithmetic mean $(n=8)$; the bars represent the standard deviation of the mean. There are no statistical differences between columns with the same letters (Fisher's LSD test, $p<0.05$ ).

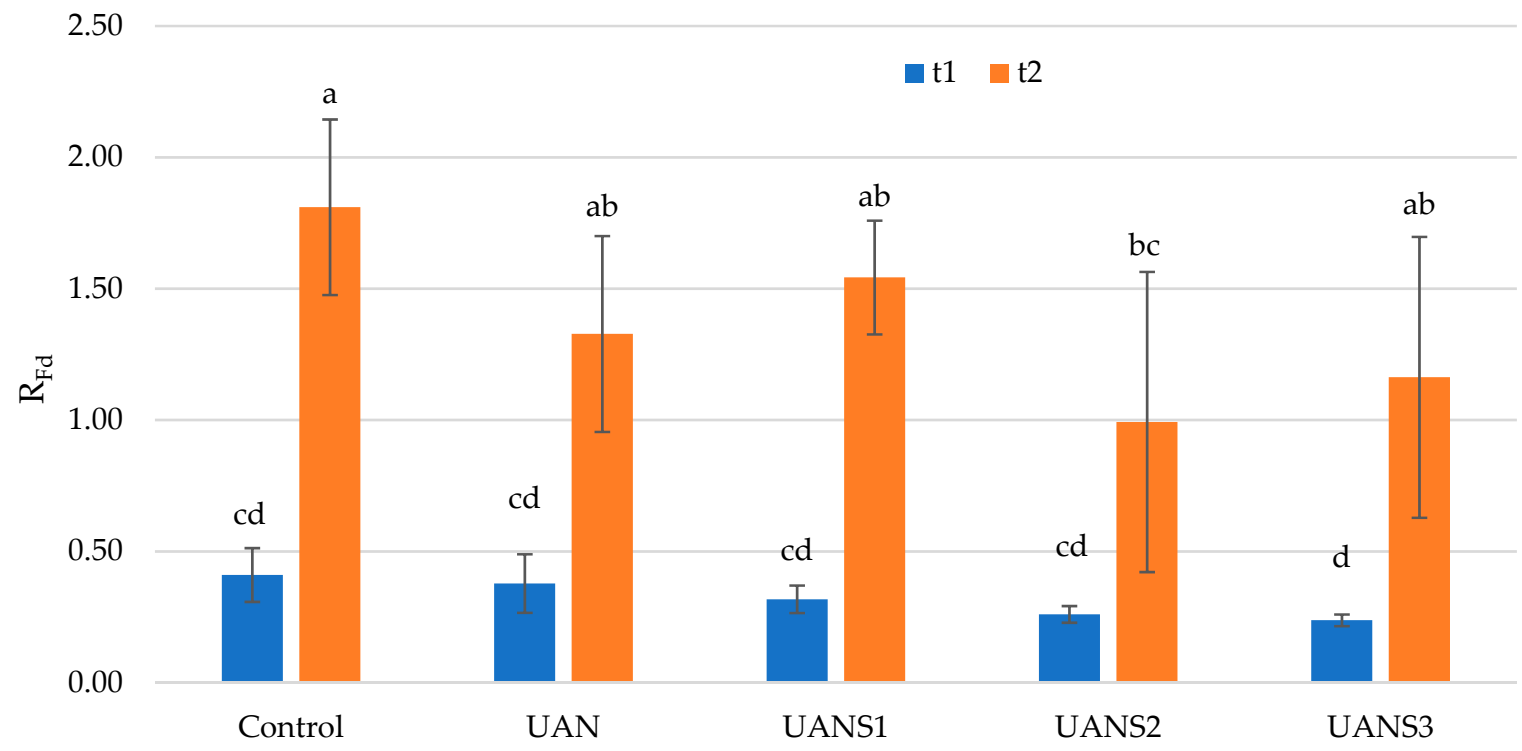

Figure 4. Fluorescence decrease ratio $\left(R_{F d}\right)$ in maize leaves after the foliar application of fertilizer. The measurements were carried out on two growth stages of maize ( $\mathrm{t} 1$ and $\mathrm{t} 2)$. The values represent the arithmetic mean $(n=8)$; the bars represent the standard deviation of the mean. There are no statistical differences between columns with the same letters (Fisher's LSD test, $p<0.05)$.

The average dry weight of the above-ground biomass (AGB) of plants determined on the 35th day after the foliar application of fertilizer ( $\mathrm{t} 3$ ) is shown in Figure 5. The highest plant dry weight was found for the treatment fertilized with UAN, which provided the most nitrogen to the plants. The dry weight of plants produced on this treatment was 2.4 times higher compared to the unfertilized Control. The dry weight of plants fertilized with the UANS fertilizer combination ranged from 17.44 to $17.84 \mathrm{~g} /$ plant and was not statistically different from the UAN treatment (Figure 5). A significant effect of foliar 
nitrogen application on plant dry matter yield has been demonstrated in the available literature [57-59], in agreement with our results. The increase in plant weight due to foliar sulfur fertilization was also documented. Perveen et al. [60] observed a significant increase in root and shoot biomass and root and shoot length of maize grown under salinity conditions due to the foliar application of different sulfur compounds. An increased barley yield after elemental sulfur application was described by Grzebisz and Przygocka-Cyna [61] in their long-term experiment. A positive effect of the foliar application of sulfur on canola pods formation and subsequent seed yield was demonstrated by Khalid et al. [62].

25

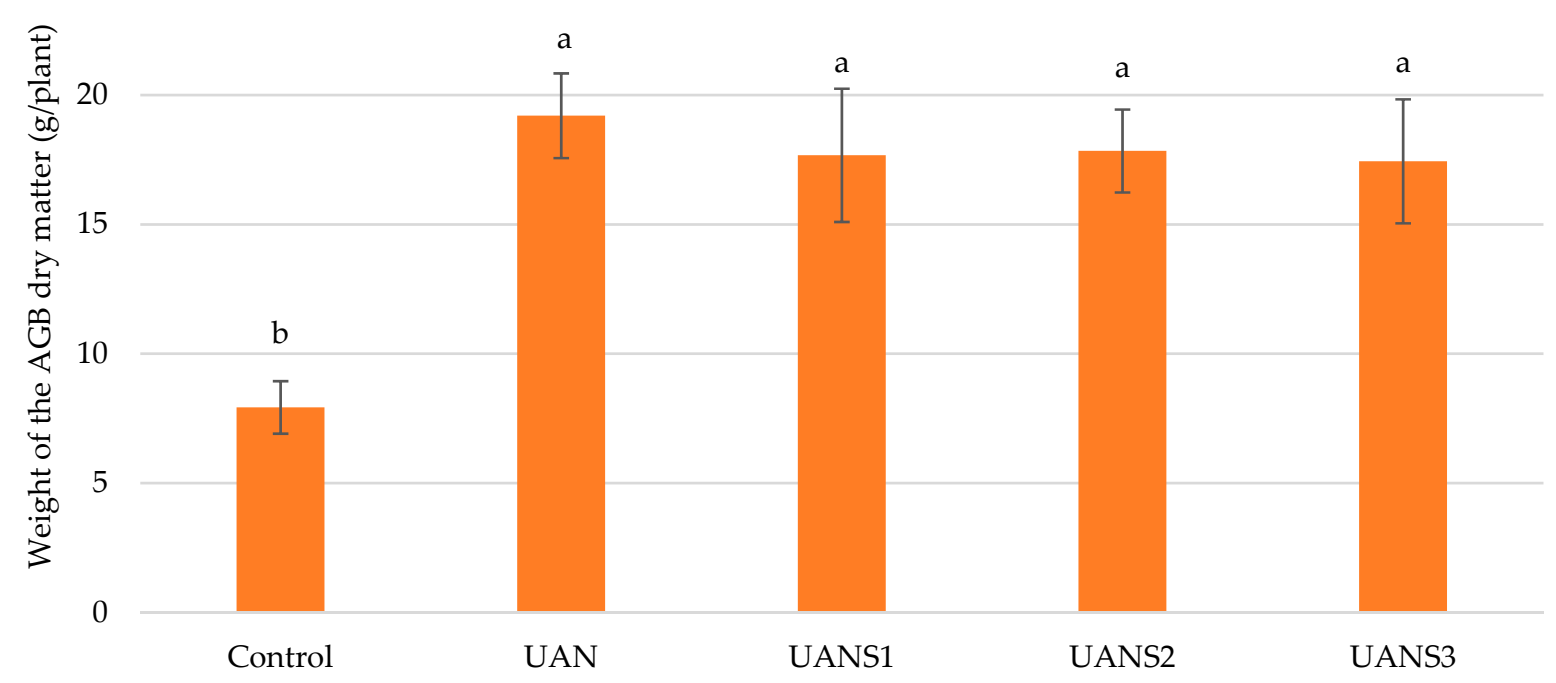

Figure 5. Weight of dry matter above-ground biomass of maize after the foliar application of fertilizer. The measurements were taken at the end of experiment $(\mathrm{t} 3)$. The values represent the arithmetic mean $(n=8)$; the bars represent the standard deviation of the mean. There are no statistical differences between columns with the same letters (Fisher's LSD test, $p<0.05$ ). AGB-above-ground biomass.

The UAN fertilizer application significantly increased the nitrogen content of maize leaves. The highest $\mathrm{N}$ content, $10.3 \mathrm{~g} / \mathrm{kg} \mathrm{DM}$, was found in leaves after the application of UAN fertilizer alone (Table 2). There was no significant difference in plant $\mathrm{N}$ content among treatments fertilized with a mixture of UAN and elemental sulfur (UANS1-3), but the data showed a relative increase in $\mathrm{N}$ content with sulfur rate. An increased leaf $\mathrm{N}$ concentration following sulfur fertilization has also been described [31,63]. An increase in the nitrogen content of wheat grain, due to the foliar application of sulfur, was observed by Tea et al. [64] and Rossini et al. [65]. This effect could be due to a better assimilation of foliar-applied $\mathrm{N}$ and $\mathrm{S}$ compared to their soil-applied counterparts.

Table 2. Nutrient content and nutrient uptake by DM of AGB and the N:S ratio.

\begin{tabular}{cccccc}
\hline \multirow{2}{*}{ Treatment } & \multicolumn{2}{c}{ Nitrogen } & \multicolumn{2}{c}{ Sulfur } & \multirow{2}{*}{ N:S Ratio } \\
\cline { 2 - 5 } & g/kg DM & Rel. $\%$ & g/kg DM & Rel. \% & \\
\hline Control & $7.7 \pm 0.8^{\mathrm{b}}$ & 100.0 & $3.4 \pm 0.6^{\mathrm{a}}$ & 100.0 & $2.3 \pm 0.5^{\mathrm{b}}$ \\
UAN & $10.3 \pm 1.8^{\mathrm{a}}$ & 134.0 & $2.8 \pm 0.6^{\mathrm{b}}$ & 80.9 & $3.8 \pm 0.4^{\mathrm{a}}$ \\
UANS1 & $9.3 \pm 0.6^{\mathrm{a}}$ & 121.6 & $3.6 \pm 0.4^{\mathrm{a}}$ & 104.4 & $3.1 \pm 0.8^{\mathrm{ab}}$ \\
UANS2 & $9.7 \pm 0.7^{\mathrm{a}}$ & 127.1 & $3.3 \pm 1.3^{\mathrm{a}}$ & 97.1 & $3.4 \pm 1.6^{\mathrm{ab}}$ \\
UANS3 & $9.9 \pm 0.5^{\mathrm{a}}$ & 129.7 & $3.3 \pm 0.7^{\mathrm{a}}$ & 97.8 & $2.6 \pm 0.4^{\mathrm{ab}}$ \\
\hline
\end{tabular}

The values in the table represent the arithmetic mean $(n=8) \pm \mathrm{SD}$ (standard deviation). The same letters next to the numbers describe no statistically significant differences between the treatments (Fisher's LSD test, $p<0.05$ ). $\mathrm{DM} —$ dry matter, AGB—above-ground biomass. 
Sutar et al. [22] described the critical sulfur concentration in dry matter of maize leaves as $1.5 \mathrm{~g} / \mathrm{kg}$ DM. The sulfur content in the ABG of maize plants ranged from 2.8 to $3.6 \mathrm{~g} / \mathrm{kg}$ $\mathrm{DM}$ (Table 2). Its content in the ABG of plants grown on the treatments fertilized with a mixture of UAN and elemental sulfur (UANS1-3) was identical to that of unfertilized plants (Control). Only in the nitrogen-fertilized treatment (UAN) was the amount of sulfur significantly lowest (Table 2). This fact is not only related to the absence of sulfur in the fertilizer, but it can also be explained by the dilution of nutrients in the maize plant tissue that occurred as a result of the increase in DM weight of AGB on this treatment (Figure 5). Therefore, the nutrient uptake by the plant was calculated as a more appropriate parameter expressing the nutritional status of the plants (Figure 6). Nutrient uptake is the relationship between the DM weight of AGB and its nutrient content, expressed in $g$ of nutrient per plant (g/plant). Logically, the highest nitrogen uptake was recorded in the UAN-fertilized treatment, i.e., the treatment with the highest applied nitrogen rate. Even though nitrogen uptake by plants was not significantly different among the treatments fertilized with UAN and elemental sulfur mixtures, plants fertilized with fertilizers containing a higher proportion of elemental sulfur (UANS2 and UANS3) showed a higher uptake of nitrogen by plant AGB. A positive significant interaction between nitrogen and sulfur uptake and utilization was confirmed.

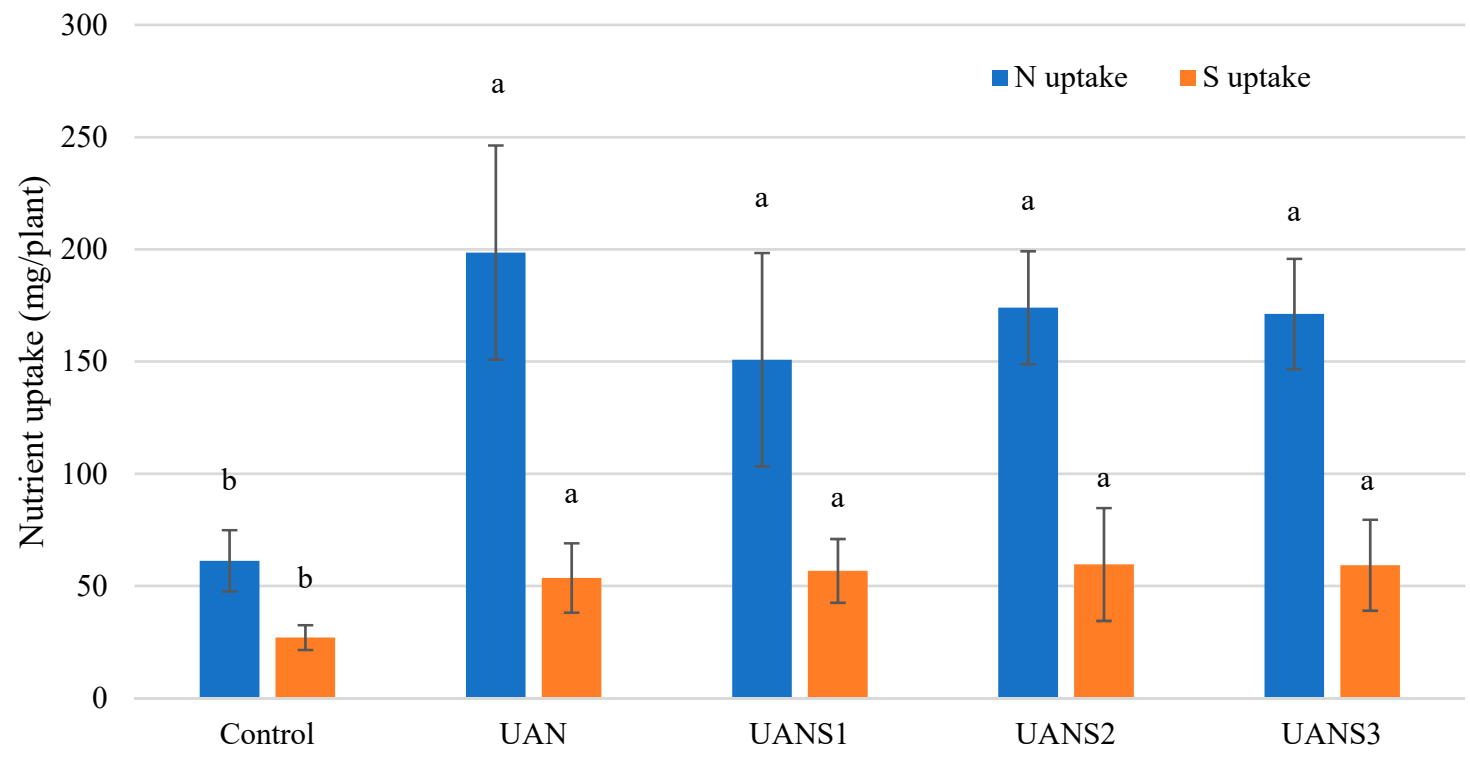

Figure 6. Nitrogen and sulfur uptake by above-ground plant biomass (mg/plant). The measurements were taken at the end of the experiment $(\mathrm{t} 3)$. The values represent the arithmetic mean $(n=8)$; the bars represent the standard deviation of the mean. There are no statistical differences between columns with the same letters (Fisher's LSD test, $p<0.05$ ).

The N:S ratio of the plant may also be an interesting indicator of nutritional status, as reported by some authors $[31,66]$. The principle behind this assessment is the fact that plants need a balanced amount of nitrogen and sulfur for proper amino acid synthesis. Therefore, nitrogen-to-sulfur ratios above a N:S ratio threshold indicate $S$ deficiency [67]. A possible disadvantage of this assessment is the decreasing value of the $\mathrm{N}: \mathrm{S}$ ratio during the growing season, as reported, for example, by Calvo et al. [68,69] or Scherer [70]. A 15-19:1 N:S ratio has been reported as a limiting ratio for cereals at the time of tillering [71], and an ideal $\mathrm{N}: \mathrm{S}$ ratio for the optimum growth and development of maize is 15:1 [72]. The observed N:S ratio (Table 2) indicated that the sulfur contained in maize was not deficient in any of the fertilization treatments. From the ratios obtained, it is possible to observe the already described trend, where the highest ratio of nitrogen and sulfur was logically found on the treatment fertilized only with UAN fertilizer. In contrast to our study, significant changes in the N:S ratio after sulfur application were observed $[73,74]$. However, they agreed that 
an increase in the sulfur content of the plant does not necessarily predict increased yield. Sutradhar et al. [31] also confirmed the same conclusion.

The previously mentioned synergism between nitrogen and sulfur can be documented by crop nitrogen use efficiency. The nitrogen supplied by foliar nutrition from fertilizer applied without sulfur addition (UAN) was utilized by the plant at $30.5 \%$ (Table 3). A similar level of $\mathrm{NUE}_{\mathrm{Crop}}$ was found on the treatment fertilized with the lowest sulfur fertilizer mixture (UANS1), whereas an increase in the proportion of sulfur in the fertilizer mixture increased nitrogen use efficiency. The relationship between nitrogen recovery from applied fertilizers and the dose of sulfur applied by the fertilizer mixture was statistically significant $\left(\mathrm{NUE}_{\mathrm{Crop}}=22.9+0.171 \times\right.$ sulfur dose, $\left.\mathrm{r}=0.709 ; p=0.002\right)$.

Table 3. Crop nitrogen use efficiency.

\begin{tabular}{ccc}
\hline & \multicolumn{3}{c}{ NUE $_{\text {Crop }}$} \\
\cline { 2 - 3 } Treatment & $\%$ & Rel. \% \\
\hline Control & - & - \\
UAN & $30.5 \pm 5.3^{\mathrm{b}}$ & 100.0 \\
UANS1 & $29.9 \pm 7.9^{\mathrm{b}}$ & 97.8 \\
UANS2 & $50.1 \pm 5.6^{\mathrm{b}}$ & 164.2 \\
UANS3 & $73.4 \pm 8.2^{\mathrm{a}}$ & 240.3 \\
\hline
\end{tabular}

The values in the table represent the arithmetic mean $(n=8) \pm \mathrm{SD}$ (standard deviation). The same letters next to the numbers describe no statistically significant differences between the treatments (Fisher's LSD test, $p<0.05$ ).

In agreement with our results, several studies showed that sulfur fertilization may increase NUE [75-77]. As sulfur is an essential constituent of enzymes involved in nitrogen metabolism [78], its deficiency may lead to ineffective utilization of the nitrogen content in plant $[79,80]$. An increase in nitrogen uptake by maize plants due to graded doses of foliar sulfur application was presented by Sarfaraz et al. [81].

\section{Materials and Methods}

\subsection{Experimental Methodology, Plant Material, and Growth Conditions}

The pot vegetation experiment was established in the vegetation hall of the Biotechnological house at Mendel University in Brno located at $49^{\circ} 21^{\prime} 03^{\prime \prime} \mathrm{N}$ and $16^{\circ} 61^{\prime} 38^{\prime \prime} \mathrm{E}$. Mitscherlich pots (STOMA GmbH, Siegburg, Germany) were filled with $6.5 \mathrm{~kg}$ of air-dried and sieved soil ( $2 \mathrm{~cm}$ diameter sieve). Properties of the soil used in the pot experiment are shown in Table 4.

Table 4. Properties of soil used in pot experiment.

\begin{tabular}{ccc}
\hline Soil Parameter & Value & Ref \\
\hline $\mathrm{pH}\left(\mathrm{CaCl}_{2}\right)$ & 6.09 & {$[82]$} \\
Soil oxidizable carbon (Cox) & $0.80 \%$ & {$[83]$} \\
Clay & $20 \%$ & {$[84]$} \\
Silt & $27 \%$ & {$[82]$} \\
Sand & $53 \%$ & {$[82]$} \\
$\mathrm{N}$ total & $164 \mathrm{mmol} / \mathrm{kg}$ & {$[82]$} \\
$\mathrm{N}^{+} \mathrm{NH}_{4}{ }^{-}\left(\mathrm{K}_{2} \mathrm{SO}_{4}\right)$ & $0.19 \%$ & {$[82]$} \\
$\mathrm{N}_{3} \mathrm{NO}_{3}^{-}\left(\mathrm{K}_{2} \mathrm{SO}_{4}\right)$ & $1.48 \mathrm{mg} / \mathrm{kg}$ & {$[82]$} \\
$\mathrm{S}\left(\mathrm{water} \mathrm{soluble}^{2}\right)$ & $17.2 \mathrm{mg} / \mathrm{kg}$ & {$[82]$} \\
$\mathrm{P}($ Mehlich 3) & $8 \mathrm{mg} / \mathrm{kg}$ & {$[82]$} \\
$\mathrm{K}($ Mehlich 3) & $36.4 \mathrm{mg} / \mathrm{kg}$ & {$[82]$} \\
$\mathrm{Ca}($ Mehlich 3) & $400 \mathrm{mg} / \mathrm{kg}$ & {$[82]$} \\
$\mathrm{Mg}$ (Mehlich 3) & $2720 \mathrm{mg} / \mathrm{kg}$ & {$[82]$} \\
\end{tabular}

The maize (Zea mays L.), cultivar SY ORPHEUS (Syngenta Czech s.r.o., Prague, Czech Republic), was chosen for this study. Four seeds of maize were sown to a $4 \mathrm{~cm}$ depth 
in each pot. The number of plants in each pot was reduced to two plants per pot two weeks after the sowing.

The pot experiment was carried out under seminatural conditions in the outdoor vegetation hall under a rain shelter. The air temperature, air humidity, and solar radiation during the maize growing season are shown in Figure 7. After a cooler April $\left(11.8^{\circ} \mathrm{C}\right)$ and May $\left(12.6^{\circ} \mathrm{C}\right)$, a warming period occurred at the beginning of June $\left(22.6^{\circ} \mathrm{C}\right)$, which lasted until the end of the experiment (average air temperature in July was $19.6^{\circ} \mathrm{C}$ ). The relative air humidity fluctuated evenly between 40 and $90 \%$ during the experiment. Global solar radiation also fluctuated over time depending on weather conditions, with levels increasing slightly during the experiment (April: 16.9; July: $22.1 \mathrm{MJ} / \mathrm{m}^{2}$ ). A controlled watering regime identical for all treatments (pots) was used in the experiment. Plants were watered to $70 \%$ of the maximum water holding capacity throughout the growing season. The pots were watered by hand with demineralized water on the soil surface.

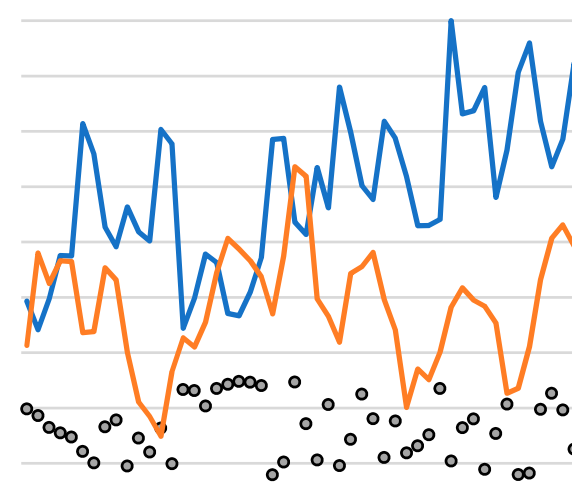

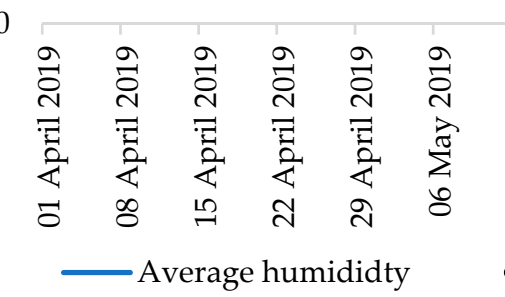
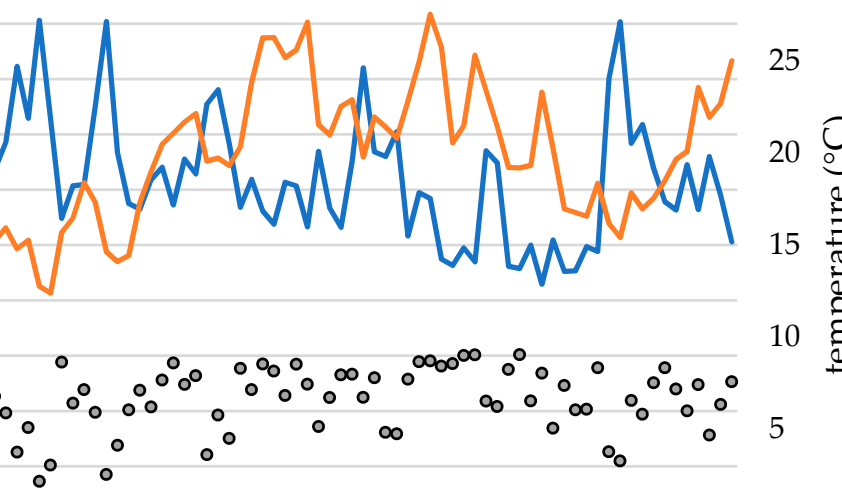

Figure 7. The average daily temperature $\left({ }^{\circ} \mathrm{C}\right)$, relative humidity $(\%)$, and global solar radiation $\left(\mathrm{MJ} / \mathrm{m}^{2}\right)$ in the vegetation hall during the experiment.

Liquid urea ammonium nitrate fertilizer (UAN; $30 \%$ total $\mathrm{N}-15 \% \mathrm{~N}-\mathrm{NH}_{2}, 7.5 \% \mathrm{~N}-\mathrm{NO}_{3}$, $7.5 \%{\mathrm{~N}-\mathrm{NH}_{4}}_{4}$ ) was applied to maize plants in combination with waste elemental sulfur suspension ( $12 \% \mathrm{~S}^{0}$ suspension) in the ratios shown in Table 5 . The sulfur suspension was obtained by the desulfurization of biogas using the Thiopaq ${ }^{\circledR}$ scrubber (Paques, Balk, The Netherlands), which works by washing the raw biogas with a slightly alkaline solution ( $\mathrm{pH}$ 8-9) and the subsequent biological oxidation of sulfides to elemental sulfur. The elemental sulfur particle size in the suspension was less than $60 \mu \mathrm{m}$ ( $96.9 \%$ of the particles). Each of the treatments was established in eight replicates (pots). The pots were placed randomly in the vegetation hall under the rain shelter.

The foliar application was carried out on the plant development stage of the 4th true leaf unfolded. The application of $3 \mathrm{~mL}$ of fertilizer mixture per pot of each treatment was used. Fertilizers were evenly applied using a pressurized hand pump sprayer (DPZ 1500, ProGlass, Weilheim an der Teck, Germany). The mixture of the waste elemental sulfur with the UAN fertilizer was mixed prior to application to ensure that the elemental sulfur was evenly distributed in the fertilizer mixture and applied uniformly.

During the maize vegetation, chlorophyll content ( $\mathrm{N}$-tester value) and chlorophyll fluorescence parameters were evaluated. The measurements were performed 7 (t1) and 
21 days (t2) after the foliar application. The weight of dry matter (DM) of maize plant AGB, the content and ratio of nutrients ( $\mathrm{N}$ and $\mathrm{S}$ ) in maize plant $\mathrm{AGB}$, and their uptake by plants were determined 35 days after the foliar application of fertilizer mixtures (t3). The schedule of the experiment is shown in Table 6.

Table 5. Experimental treatments of foliar application in pot experiment.

\begin{tabular}{ccccc}
\hline \multirow{2}{*}{ Treatment } & \multicolumn{2}{c}{$\begin{array}{c}\text { Proportion of Fertilizer in the } \\
\text { UANS Mixture }\end{array}$} & $\begin{array}{c}\text { Nutrient Content in the UANS } \\
\text { Mixture (Weight \%) }\end{array}$ \\
\cline { 2 - 5 } & UAN & S Suspension & N & S \\
\hline Control & 0 & 0 & 0 & 0 \\
UAN & $100 \%$ & 0 & 30 & 0 \\
UANS1 & $66 \%$ & $33 \%$ & 20 & 4 \\
UANS2 & $50 \%$ & $50 \%$ & 15 & 6 \\
UANS3 & $33 \%$ & $66 \%$ & 10 & 8 \\
\hline
\end{tabular}

Table 6. Timetable of the experiment.

\begin{tabular}{cccc}
\hline Term & & Growth Stages of Maize & Operation \\
\hline 1 April 2019 & & seed & Maize sowing \\
17 June 2019 & & 4th true leaf & Foliar application of fertilizer mixtures \\
24 June 2019 & t1 & 5th true leaf & Measurement of chlorophyll content and fluorescence parameters \\
8 July 2019 & t2 & 6th true leaf & Measurement of chlorophyll content and fluorescence parameters \\
22 July 2019 & t3 & 7th true leaf & Measurement of AGB harvest, DM weight, content and uptake of \\
& & & nutrient, N:S ratio \\
\hline
\end{tabular}

\subsection{Determination of Plant Growth and Development Parameters}

\subsubsection{Chlorophyll Content in Plant Leaf (N-Tester Value)}

The chlorophyll content of maize leaves was measured using a Yara N-tester (Yara International ASA, Oslo, Norway). The chlorophyll content was expressed as "N-tester value." Measurement was performed at a wavelength range of 650-940 nm [85]. Eight plants were assessed in each treatment in both terms. The measurement of chlorophyll content was performed on the 5th (t1) and 6th true leaves (t2), and the value of the chlorophyll content of each plant was the mean of 60 measurements.

\subsubsection{Chlorophyll Fluorescence Parameters}

To determine the photochemical efficiency of photosystem II, selected fluorescence parameters of chlorophyll were measured in maize plant. The tested parameters were measured with the PAR-FluorPen FP 110-LM/S (Photon Systems Instruments, Drásov, Czech Republic) and evaluated using the FluorPen 1.1 software [86]. Measurements of fluorescence parameters were carried out on identical leaves (5th and 6th true leaves) at identical terms ( $\mathrm{t} 1$ and $\mathrm{t} 2$ ) as for chlorophyll content determination. Maize leaves were dark-adapted for $25 \mathrm{~min}$ before measurement. The protocol for measuring the fluorescence parameters of chlorophyll is shown in Table 7.

The variable fluorescence of the dark-adapted leaves $\left(F_{v}\right)$, quantum yield of photosystem II $\left(\Phi_{P S I I}\right)$, and chlorophyll fluorescence decrease ratio $\left(R_{F d}\right)$ were determined (Table 8). 
Table 7. Measurement protocol of the chlorophyll fluorescence parameters.

\begin{tabular}{|c|c|c|c|c|c|c|}
\hline $\begin{array}{c}\text { Chlorophyll Fluorescence } \\
\text { Parameters }\end{array}$ & Pulse Type & $\begin{array}{l}\text { Light Intensity } \\
\left(\mu \mathrm{mol} / \mathrm{m}^{2} / \mathrm{s}\right)\end{array}$ & Phase & Duration (s) & 1st Pulse (s) & Pulse Interval (s) \\
\hline$\Phi_{\text {PSII }}, F_{v}$ & Saturation & 2400 & - & 1 pulse & & \\
\hline \multirow{5}{*}{$R_{F d}$} & \multirow{2}{*}{ Flash } & \multirow{2}{*}{900} & $\mathrm{~L}$ & 60 & 0.2 & 1 \\
\hline & & & DR & 88 & 1 & 1 \\
\hline & \multirow{2}{*}{ Saturation } & \multirow{2}{*}{2400} & $\mathrm{~L}$ & 60 & 7 & 12 \\
\hline & & & DR & 88 & 11 & 26 \\
\hline & Actinic & 300 & $\mathrm{~L}$ & 60 & - & - \\
\hline
\end{tabular}

The measured at wavelength $(\lambda)$ of $454 \mathrm{~nm}$, L-light, DR—dark recovery, $\Phi_{P S I I}$-quantum yield of photosystem II, $R_{F d}$-chlorophyll fluorescence decrease ratio, $F_{v}$-variable fluorescence of the dark-adapted leaves.

Table 8. The photochemical quenching parameters.

\begin{tabular}{ccc}
\hline Chlorophyll Fluorescence Parameters & Ref. \\
\hline$F_{v}$ & $F_{m}-F_{0}$ & {$[87]$} \\
$\Phi_{P S I I}$ & $F_{m}-F_{0} / F_{m}$ & {$[88]$} \\
$R_{F d}$ & $F_{d} / F_{S}$ & {$[89]$} \\
\hline$F_{0}-$ minimal fluorescence from the dark-adapted leaves, $\Phi_{P S I I}$-quantum yield of photosystem II, $R_{F d}$-chlorophyll \\
fluorescence decrease ratio, $F_{m}$ - maximal fluorescence from the dark-adapted leaves; $F_{d}$ - fluorescence decrease \\
from $F_{m}$ to $F_{s} ; F_{s}$ - steady-state chlorophyll fluorescence.
\end{tabular}

\subsubsection{Determination of Weight Biomass, Nutrient Contents and Uptake, and Nitrogen Use Efficiency}

The ABG of maize plants was harvested on 22 July 2019 (t3). The ABG was then ovendried at $60{ }^{\circ} \mathrm{C}$ for the first two hours. The temperature was then reduced to $45^{\circ} \mathrm{C}$ where the samples were kept for $72 \mathrm{~h}$. The dry weight of $A B G$ was determined using a laboratory-scale PCB Kern (KERN \& Sohn GmbH, Balingen, Germany). Then, the dried ABG was crushed and homogenized by the grinder Grindomix GM200 (Retsch GmbH, Haan, Germany). The $\mathrm{HNO}_{3} / \mathrm{H}_{2} \mathrm{O}_{2}$ [90] digestion of biomass was achieved using a microwave digestion system in ETHOS 1 (Milestone Srl, Sorisole, Italy). Subsequently, the nutrient content (Table 9) and nutrient ratio were determined, and crop nitrogen use efficiency $\left(\mathrm{NUE}_{\mathrm{Crop}}\right)$ was calculated by the relationship $\mathrm{NUE}_{\mathrm{Crop}}=\mathrm{N}$ yield $/ \mathrm{N}$ input $\cdot 100(\mathrm{~N}$ yield $=$ nitrogen uptake by plants $(\mathrm{mg} / \mathrm{pot}) ; \mathrm{N}$ input = nitrogen applied by foliar fertilizers $(\mathrm{mg} / \mathrm{pot}))$ [91]. In the calculation of $\mathrm{NUE}_{\mathrm{Crop}}$, the nitrogen uptake by plants grown on the fertilized treatments ( $\mathrm{N}$ yield) was subtracted from the nitrogen uptake observed on the control treatment (this amount of nitrogen characterized the natural soil supply).

Table 9. The methods for the determination of nutrients in maize AGB.

\begin{tabular}{ccccc}
\hline Nutrient & Method Used & Device Used & Ref. \\
\hline $\mathrm{N}$ & Kjeldal method & Kjeltec 2300 device (Foss Analytical, Hillerød, Denmark) & [92] \\
\hline $\mathrm{S}$ & Optical emission spectrometry & ICP-OES (Spectro, Kleve, Germany) & [93] \\
\hline
\end{tabular}

\subsection{Statistical Data Analysis}

The effect of the foliar application of fertilizer mixtures on the plant growth and development parameters was statistically analyzed by the STATISTICA 12 program (TIBCO Software, San Jose, CA, USA) [94]. The effect of the foliar application on the N-tester value, chlorophyll fluorescence parameters, dry weight of ABG, and nutrient content ABG of maize was analyzed separately for each treatment of the experiment. The normality was checked using the Shapiro-Wilk test, and the homogeneity was verified by the Levene test at $p \leq 0.05$. The effect of fertilization was analyzed using ANOVA. Fisher's LSD test $(p \leq 0.05)$ was used to determine any statistically significant differences between the means of treatments. 


\section{Conclusions}

Nitrogen plays an important role in maize nutrition, contributes to chlorophyll formation, and significantly influences the photosynthetic activity of plants. The result of the vegetation experiment showed that the efficiency of mineral nitrogen fertilization can be increased by the foliar application of liquid fertilizers with sulfur addition. The optimal adjustment of the ratio of applied nutrients ( $\mathrm{N}$ and $\mathrm{S}$ ) improves the nutritional status of the plants and allows the reduction in their doses while minimizing the environmental risks associated with fertilization. The foliar application of UAN fertilizer in combination with elemental sulfur from biogas production in a 1:1 ratio seems to be a sensible way to optimize the nutritional status of maize, both for the economics of biogas purification, when the waste sulfur is reused as a fertilizer, and for environmental reasons. However, verification of the results obtained from the pot experiment in field trials will be necessary.

Author Contributions: Conceptualization, P.Š. and J.A.; methodology, P.Š., J.A. and M.B.; validation, J.A. and P.Š.; investigation and data analyses, J.A. and P.Š.; resources, J.A., M.B., A.K. and P.Š.; writing—original draft preparation, P.Š. and J.A.; writing-review and editing, P.R., M.B., A.K. and T.H.; project administration, M.B.; funding acquisition, M.B. All authors have read and agreed to the published version of the manuscript.

Funding: This research was funded by the Technology Agency of the Czech Republic, grant TH04030142: Utilization of Biogas Waste to Improve Soil Properties and Increase Sulphur Content of Plants.

Data Availability Statement: The data presented in this study are available on request from the corresponding author. Due to the nature of this research, participants of this study did not agree for their data to be shared publicly, so supporting data are not available.

Conflicts of Interest: The authors declare no conflict of interest.

\section{References}

1. European Commission. The European Green Deal. COM(2019) 640 Final; European Commission: Brussels, Belgium, 2019. Available online: https:// eur-lex.europa.eu/legal-content/EN/TXT/?uri=COM\%3A2019\%3A640\%3AFIN (accessed on 13 September 2021).

2. Arnau, Á.S.; Pflüger, S.; Giacomazzi, M.; Decorte, M.; Genua, M. Annual Report 2020; European Biogas Association: Brussels, Belgium. Available online: https:/ / www.europeanbiogas.eu/eba-annual-report-2020/ (accessed on 7 September 2021).

3. European Biogas Association-EBA. European Biogas Association Statistical Report 2020; European Biogas Association: Brussels, Belgium, 2021.

4. Fontaine, D.; Eriksen, J.; Sørensen, P. Sulfur from biogas desulfurization: Fate of S during storage in manure and after application to plants. Sci. Total Environ. 2021, 754, 142180. [CrossRef] [PubMed]

5. Okoro, O.V.; Sun, Z. Desulphurisation of biogas: A systematic qualitative and economic-based quantitative review of alternative strategies. Chem. Eng. 2019, 3, 76. [CrossRef]

6. Allegue, L.B.; Hinge, J.H. Biogas Upgrading Evaluation for H2S Removal; Danish Technology Institute: Taastrup, Denmark, 2014.

7. Fernández-Delgado, J.M.; Mostbauer, P.; Knapp, A.; Müller, W.; Tertsch, S.; Bockreis, A.; Insam, H. Biogas purification with biomass ash. Waste Manag. 2018, 71, 224-232. [CrossRef]

8. Pacheco da Costa, T.; Quinteiro, P.; Tarelho, L.A.C.; Arroja, L.; Dias, A.C. Life cycle assessment of woody biomass ash for soil amelioration. Waste Manag. 2020, 101, 126-140. [CrossRef] [PubMed]

9. Degryse, F.; Ajiboye, B.; Baird, R.; da Silva, R.C.; McLaughlin, M.J. Oxidation of elemental sulfur in granular fertilizers depends on the soil-exposed surface area. Soil Sci. Soc. Am. J. 2016, 80, 294-305. [CrossRef]

10. Hoesly, R.M.; Smith, S.J.; Feng, L.; Klimont, Z.; Janssens-Maenhout, G.; Pitkanen, T.; Seibert, J.J.; Vu, L.; Andres, R.J.; Bolt, R.M.; et al. Historical (1750-2014) anthropogenic emissions of reactive gases and aerosols from the Community Emission Data System (CEDS). Geosci. Model Dev. 2017, 11, 369-408. [CrossRef]

11. Engardt, M.; Simpson, D.; Schwikowski, M.; Granat, L. Deposition of sulphur and nitrogen in Europe 1900-2050. Model calculations and comparison to historical observations. Tellus B Chem. Phys. Meteorol. 2017, 69, 1328945. [CrossRef]

12. Czech Hydrometeorological Institute, IX. Atmospheric Deposition in the Territory of the Czech Republic. 2019. Available online: https://www.chmi.cz/files/portal/docs/uoco/isko/grafroc/19groc/gr19cz/09_depozice_v1.pdf (accessed on 11 September 2021). (In Czech).

13. Eriksen, J. Gross sulfur mineralisation-immobilisation turnover in soil amended with plant residues. Soil Biol. Biochem. 2005, 37, 2216-2224. [CrossRef] 
14. Lehman, J.; Solomon, D.; Zhao, F.J.; McGrath, S.P. Atmospheric $\mathrm{SO}_{2}$ emissions since the late 1800s change organic sulfur forms in humic substance extracts of soils. Environ. Sci. Technol. 2008, 42, 3550-3555. [CrossRef]

15. Balík, J.; Kulhánek, M.; Černý, J.; Száková, J.; Pavlíková, D.; Čermák, P. Differences in soil sulfur fractions due to limitation of atmospheric deposition. Plant Soil Environ. 2009, 55, 344-352. [CrossRef]

16. Kulhánek, M.; Balík, J.; Černý, J.; Sedlář, O.; Vašák, F. Evalu-ating of soil sulfur forms changes under different fertilizing systems during long-term field experiments. Plant Soil Environ. 2016, 62, 408-415. [CrossRef]

17. Scherer, H.W. Sulfur in soils. J. Plant Nutr. Soil Sci. 2009, 172, 326-335. [CrossRef]

18. Feinberg, A.; Stenke, A.; Peter, T.; Hinckley, E.L.S.; Driscoll, C.T.; Winkel, L.H.E. Reductions in the deposition of sulfur and selenium to agricultural soils pose risk of future nutrient deficiencies. Commun Earth Environ. 2021, 2, 101. [CrossRef]

19. Zbíral, J.; Smatanová, M.; Němec, P. Sulphur status in agricultural soil determined using the Mehlich 3 method. Plant Soil Environ. 2018, 64, 255-259.

20. Eriksen, J. Soil sulfur cycling in temperate agricultural systems. Adv. Agron. 2009, 102, 55-89.

21. Schoenau, J.J.; Malhi, S.S.; Jez, J. Sulfur Forms and Cycling Processes in Soil and Their Relationship to Sulfur Fertility. In Sulfur: A Missing Link between Soils, Crops, and Nutrition; Jez, J., Ed.; American Society of Agronomy: Masidon, WI, USA, 2008; pp. 1-10.

22. Sutar, R.K.; Pujar, A.M.; Aravinda Kumar, B.N.; Hebsur, N.S. Sulphur nutrition in maize-A critical review. Int. J. Pure Appl. Biosci. 2017, 5, 1582-1596. [CrossRef]

23. Fishmes, J.; Vong, P.C.; Guckert, A.; Frossard, E. Influence of sulfur on apparent N-use efficiency, yield and quality of oilseed rape (Brassica napus L.) grown on a calcareous soil. Eur. J. Agron. 2000, 12, 127-141. [CrossRef]

24. Tabak, M.; Lepiarczyk, A.; Filipek-Mazur, B.; Lisowska, A. Efficiency of Nitrogen Fertilization of Winter Wheat Depending on Sulfur Fertilization. Agronomy 2020, 10, 1304. [CrossRef]

25. Salvagiotti, F.; Miralles, D.J. Radiation interception, biomass production and grain yield as affected by the interaction of nitrogen and sulfur fertilization in wheat. Eur. J. Agron. 2008, 28, 282-290. [CrossRef]

26. Carciochi, W.D.; Divito, G.A.; Fernández, L.A.; Echeverría, H.E. Sulfur affects root growth and improves nitrogen recovery and internal efficiency in wheat. J. Plant Nutr. 2017, 40, 1231-1242. [CrossRef]

27. Swamy, U.; Wang, M.; Tripathy, J.N.; Kim, S.K.; Hirasawa, M.; Knaff, D.B.; Allen, J.P. Structure of spinach nitrite reductase: Implications for multi-electron reactions by the iron-sulfur: Siroheme cofactor. Biochemistry 2005, 44, 16054-16063. [CrossRef]

28. Mendel, R. Molybdenum cofactor of higher plants: Biosynthesis and molecular biology. Planta 1997, 203, 399-405. [CrossRef]

29. Salvagiotti, F.; Castellarín, J.; Miralles, D.J.; Pedrol, H.M. Sulfur efficiency in wheat by increasing nitrogen uptake. Field Crop. Res. 2009, 113, 170-177. [CrossRef]

30. Haneklaus, S.; Bloem, E.; Schnug, E. Sulfur. In Encyclopedia of Soil Science; La, R., Ed.; Marcel Dekker, Inc.: New York, NY, USA, 2002; pp. 1282-1288.

31. Sutradhar, A.K.; Kaiser, D.E.; Fernández, F.G. Does total nitrogen/sulfur ratiopredict nitrogen or sulfur requirement for corn? Soil Sci. Soc. Am. J. 2017, 81, 564-577. [CrossRef]

32. Carciochi, W.D.; Wyngaard, N.; Divito, G.A.; Reussi Calvo, N.I.; Cabrera, M.L.; Echeverría, H.E. Diagnosis of sulfur availability for corn based on soil analysis. Biol. Fertil. Soils 2016, 52, 917-926. [CrossRef]

33. Wilhelm, W.; McMaster, G.; Harrell, D.M. Nitrogen and dry matter distribution by culm and leaf position at two stages of vegetative growth in winter wheat. Agron. J. 2002, 94, 1078-1086. [CrossRef]

34. Smoleń, S. Foliar Nutrition: Current State of Knowledge and Opportunities. In Advances in Citrus Nutrition; Srivastava, A.K., Ed.; Springer Science \& Business Media: Dordrecht, The Netherlands, 2012; pp. 41-58.

35. Baloch, N.; Buriro, M.; Jato, G.H.; Ali, K.; Khaskheli, D.M.A.; Nahiyoon, S.A.; Hou, P.; Li., S. Effect of foliar application of nitrogen on growth, yield and grain quality parameters of wheat (Triticum aestivum L.). Biocell 2019, 43, 261-267.

36. Mortate, R.K.; Nascimento, E.F.; Goncalves, E.G.D.; Lima, M.W.D. Response of maize (Zea mays L.) to nitrogen fertilizer application in the soil and foliar. Rev. Agric. Neotrop. 2018, 5, 1-6. [CrossRef]

37. Dong, S.; Neilsen, D.; Neilsen, G.H.; Fuchigami, L.H. Foliar $\mathrm{N}$ application reduces soil $\mathrm{NO}_{3}{ }^{-}-\mathrm{N}$ leaching loss in apple orchards. Plant Soil 2005, 268, 357-366. [CrossRef]

38. Niu, J.; Liu, C.; Huang, M.; Liu, K.; Yan, D. Effect of Foliar Fertilization: A Review of Current and Future Perspectives. J. Soil Sci. Plant Nutr. 2021, 21, 104-118. [CrossRef]

39. Voogt, W.; Blok, C.; Eveleens-Clark, B.; Marcelis, L.F.M.; Bindraban, P.S. Foliar Fertilizer Application; VFRC Report 2013/2; Virtual Fertilizer Research Center: Washington, DC, USA, 2013; p. 43.

40. Fernández, V.; Brown, P.H. From plant surface to plant metabolism: The uncertain fate of foliar-applied nutrients. Front. Plant Sci. 2013, 4, 289. [CrossRef]

41. Mahmoodi, P.; Yarnia, M.; Amirnia, R.; Benam, M.B.K. Effect of nitrogen foliar application on grain filling rate and period in 3 cultivars of corn (Zea mays L.). Afr. J. Agric. Res. 2011, 81, 783-786.

42. Islam, M.S.; Akter, H.; Aktar, S.; Miah, M.J.; Farazi, M. Effect of foliar and soil application of nitrogen on the growth and yield of wheat. Progress. Agric. 2017, 28, 287-294. [CrossRef]

43. Ercoli, L.; Mariotti, M.; Masoni, A.; Massantini, F. Relationship between nitrogen and chlorophyll content and spectral properties in maize leaves. Eur. J. Agron. 1993, 2, 113-117. [CrossRef]

44. Li, C. Effects of Enhanced Ammonium Nutrition on Growth and Development of Maize. J. Northeast. Agric. Univ. 2002, $33,313-318$. 
45. Schlemmer, M.; Gitelson, A.; Schepers, J.; Ferguson, R.; Peng, Y.; Shanahan, J.; Rundquist, D. Remote estimation of nitrogen and chlorophyll contents in maize at leaf and canopy levels. Int. J. Appl. Earth Obs. Geoinf. 2013, 25, 47-54. [CrossRef]

46. Mu, X.; Chen, Q.; Chen, F.; Yuan, L.; Mi, G. A RNA-seq Analysis of the Response of Photosynthetic System to Low Nitrogen Supply in Maize Leaf. Int. J. Mol. Sci. 2017, 18, 2624. [CrossRef]

47. Yue, K.; Li, L.; Xie, J.; Fudjoe, S.K.; Zhang, R.; Luo, Z.; Anwar, S. Nitrogen Supply Affects Grain Yield by Regulating Antioxidant Enzyme Activity and Photosynthetic Capacity of Maize Plant in the Loess Plateau. Agronomy 2021, 11, 1094. [CrossRef]

48. Chapman, S.C.; Barreto, H.J. Using a chlorophyll meter to estimate specific leaf nitrogen of tropical maize during vegetative growth. Agron. J. 1997, 89, 557-562. [CrossRef]

49. Lacroux, F.; Tregoat, O.; van Leeuwen, C.; Pons, A.; Tominaga, T.; Lavigne-Cruége, V.; Dubourdieu, D. Effect of Foliar Nitrogen and Sulphur Application on Aromatic Expression of Vitis Vinifera L. cv. Sauvignon Blanc. J. Int. Sci. Vigne Vin 2008, 42, 125-132. [CrossRef]

50. Rascher, U.; Liebig, M.; Luttge, U. Evaluation of instant light-response curves of chlorophyll fluorescence parameters obtained with a portable chlorophyll fluorometer on site in the field. Plant Cell Environ. 2000, 23, 1397-1405. [CrossRef]

51. Ciompi, S.; Gentili, E.; Guidi, L.; Soldatini, G.E. The effect of nitrogen deficiency on leaf gas exchange and chlorophyll fluorescence parameters in sunflower. Plant Sci. 1996, 118, 177-184. [CrossRef]

52. Jin, X.; Yang, G.; Tan, C.; Zhao, C. Effects of nitrogen stress on the photosynthetic $\mathrm{CO}_{2}$ assimilation, chlorophyll fluorescence and sugar-nitrogen ratio in corn. Sci. Rep. 2015, 5, 9311. [CrossRef]

53. Ahmad, I.; Ahmad, S.; Kamran, M.; Yang, X.N.; Hou, F.J.; Yang, B.P.; Ding, R.X.; Liu, T.; Han, Q.F. Uniconazole and nitrogen fertilization trigger photosynthesis and chlorophyll fluorescence, and delay leaf senescence in maize at a high population density. Photosynthetica 2021, 59, 192-202. [CrossRef]

54. Nunes, M.A.; Ramalho, J.C.; Dias, M.A. Effect of nitrogen supply on the photosynthetic performance of leaves from coffee plants exposed to bright light. J. Exp. Bot. 1993, 262, 893-899. [CrossRef]

55. Verhoeven, A.S.; Demmig-Adams, B.; Adams, W.W., III. Enhanced employment of the xanthophyll cycle and thermal energy dissipation in spinach exposed to high light and N stress. Plant Physiol. 1997, 113, 817-824. [CrossRef] [PubMed]

56. Fryer, M.J.; Andrews, J.R.; Oxborough, K.; Blowers, D.A.; Baker, N.R. Relationship between $\mathrm{CO}_{2}$ assimilation, photosynthetic electron transport, and active $\mathrm{O}_{2}$ metabolism in leaves of maize in the field during periods of low temperature. Plant Physiol. 1998, 116, 571-580. [CrossRef]

57. Palta, J.A.; Kumari, S.; Spring, C.; Turner, N.C. Foliar nitrogen applications increase the seed yield and protein content in chickpea (Cicer arietinum L.) subject to terminal drought. Aust. J. Agric. Res. 2005, 56, 105-112. [CrossRef]

58. Gholami, A.; Akhlaghi, S.; Shahsavani, S.; Farrokhi, N. Effects of Urea Foliar Application on Grain Yield and Quality of Winter Wheat. Commun. Soil Sci. 2011, 42, 719-727. [CrossRef]

59. Mbangcolo, M.M.; Pieterse, P.J. Effect of soil- and foliar-applied nitrogen fertiliser on growth, yield and protein content of spring wheat (Triticum aestivum L.) under glasshouse conditions. S. Afr. J. Plant Soil 2018, 35, 237-239. [CrossRef]

60. Perveen, S.; Iqbal, N.; Saeed, M.; Zafar, S.; Arshad, Z. Role of foliar application of sulfur-containing compounds on maize (Zea mays L. var. Malka and hybrid DTC) under salt stress. Rev. Bras. Bot. 2018, 41, 805-815. [CrossRef]

61. Grzebisz, W.; Przygocka-Cyna, K. Spring malt barley response to elemental sulphur-The prognostic value of N and S concentrations in malt barley leaves. Plant Soil Environ. 2007, 53, 338-394. [CrossRef]

62. Khalid, S.; Afridi, M.Z.; Munsif, F.; Imranuddin, I.; Ullah, N.; Ullah, I. Effect of Sulphur Foliar Application on Yield and Yield Components of Brassica Napus. Int. J. Agric. Environ. Res. 2016, 2, 232-236.

63. Carciochi, W.D.; Nahuel, I.; Calvo, R.; Wyngaard, N.; Divito, G.A. Prognosis and diagnosis of sulfur status in maize by plant analysis. Eur. J. Agron. 2019, 108, 1-10. [CrossRef]

64. Tea, I.; Genter, T.; Naulet, N.; Lummerzheim, M.; Kleiber, D. Interaction between nitrogen and sulfur by foliar application and its effects on flour bread-making quality. J. Sci. Food Agric. 2007, 87, 2853-2859. [CrossRef]

65. Rossini, F.; Provenzano, M.E.; Sestili, F.; Ruggeri, R. Synergistic Effect of Sulfur and Nitrogen in the Organic and Mineral Fertilization of Durum Wheat: Grain Yield and Quality Traits in the Mediterranean Environment. Agronomy 2018, 8, 189. [CrossRef]

66. Rehm, G.W.; Clapp, J.G. Sulfur in a Fertilizer Program for Corn. In Sulfur: A Missing Link Between Soils, Crops, and Nutrition; Jez, J., Ed.; American Society of Agronomy: Masidon, WI, USA, 2008; pp. 143-152.

67. Haneklaus, S.; Bloem, E.; Schnug, E. Sulfur Interactions in Crop Ecosystems. In Sulfur in Plants an Ecological Perspective; Hawkesford, M.J., De Kok, L.J., Eds.; Springer: Dordrecht, The Netherlands, 2007; pp. 16-58.

68. Reussi Calvo, N.I.; Echeverría, H.E.; Sainz Rozas, H. Usefulness of foliar nitrogen-sulfur ratio in spring red wheat. J. Plant Nutr. 2008, 31, 1612-1623. [CrossRef]

69. Reussi Calvo, N.I.; Echeverría, H.E.; Sainz Rozas, H.R. Stability of foliar nitrogen: Sulfur ratio in spring red wheat and sulfur dilution curve. J. Plant Nutr. 2012, 35, 990-1003. [CrossRef]

70. Scherer, H.W. Sulphur in crop production. Eur. J. Agron. 2001, 14, 81-111. [CrossRef]

71. Reussi Calvo, N.I.; Echeverŕia, H.; Rozas, H.S. Diagnosing sulfur deficiency in spring red wheat: Plant analysis. J. Plant Nutr. 2011, 34, 573-589. [CrossRef]

72. Zenda, T.; Liu, S.; Dong, A.; Duan, H. Revisiting Sulphur-The Once Neglected Nutrient: It's Roles in Plant Growth, Metabolism, Stress Tolerance and Crop Production. Agriculture 2021, 11, 626. [CrossRef] 
73. Kaiser, D.E.; Kim, K.I. Soybean response to sulfur fertilizer applied as a broadcast or starter using replicated strip trials. Agron. J. 2013, 105, 1189-1198. [CrossRef]

74. Kaur, J.; Chatterjee, A.; Franzen, D.; Cihacek, L. Corn Response to Sulfur Fertilizer in the Red River Valley. Agron. J. 2019, 111, 2378-2386. [CrossRef]

75. Till, A.R. Sulphur and Sustainable Agriculture, 1st ed.; International Fertilizer Industry Association: Paris, France, 2010; pp. 1-70.

76. Kacjan Maršić, N.; Može, K.S.; Mihelič, R.; Nečemer, M.; Hudina, M.; Jakopič, J. Nitrogen and Sulphur Fertilisation for Marketable Yields of Cabbage (Brassica oleracea L. var. Capitata), Leaf Nitrate and Glucosinolates and Nitrogen Losses Studied in a Field Experiment in Central Slovenia. Plants 2021, 10, 1304. [CrossRef] [PubMed]

77. Yu, Z.; She, M.; Zheng, T.; Diepeveen, D.; Islam, S.; Zhao, Y.; Zhang, Y.; Tang, G.; Zhang, Y.; Zhang, J.; et al. Impact and mechanism of sulphur-deficiency on modern wheat farming nitrogen-related sustainability and gliadin content. Commun. Biol. 2021, 4, 945. [CrossRef] [PubMed]

78. Hawkesford, M.; Horst, W.; Kichey, T.; Lambers, H.; Schjoerring, J.; Skrumsager, I.; White, P. Functions of Macronutrients. In Marschner's Mineral Nutrition of Higher Plants, 3rd ed.; Marschner, H., Ed.; Academic Press: London, UK, 2012 ; pp. 135-189.

79. Jamal, A.; Moon, Y.; Abdin, M.Z. Sulphur-A general overview and interaction with nitrogen. Aust. J. Crop Sci. 2010, 4, 523-529.

80. Ali, A.; Iqbal, Z.; Hassan, S.W.; Yasin, M.; Khaliq, T.; Ahmed, S. Effect of nitrogen and sulphur on phenology, growth and yield parameters of maize crop. Sci. Int. 2013, 25, 363-366.

81. Sarfaraz, Q.; Perveen, S.; Shahab, Q.; Muhammad, D.; Bashir, S.; Ahmed, N.; Ahmed, S.; Shahid-Ul-Islam, M.; Asghar, I. Comparative Effect of Soil and Foliar Application of Sulfur on Maize. IOSR J. Agric. Vet. Sci. 2014, 7, 32-37. [CrossRef]

82. Zbíral, J.; Malý, S.; Váňa, M. (Eds.) Soil Analysis III, 3rd ed.; Central Institute for Supervising and Testing in Agriculture: Brno, Czech Republic, 2011; pp. 18-52. (In Czech)

83. Schumacher, B.A. Methods for the Determination of Total Organic Carbon (TOC) in Soils and Sediments; United States Environmental Protection Agency, Environmental Sciences Division National, Exposure Research Laboratory: Las Vegas, NV, USA, 2002.

84. Gee, G.W.; Bauder, J.W. Particle-Size Analysis. In Methods of Soil Analysis Part 1—Physical and Mineralogical Methods; Klute, A., Ed.; ASA and SSSA: Madison, WI, USA, 1986; pp. 383-411.

85. Netto, A.L.; Campostrini, E.; Goncalves de Oliverira, J.; Bressan-Smith, R.E. Photosynthetic pigments, nitrogen, chlorophyll a fluorescence and SPAD-502 readings in coffee leaves. Sci. Hortic. 2005, 104, 199-209. [CrossRef]

86. Škarpa, P.; Klofáč, D.; Krčma, F.; Šimečková, J.; Kozáková, Z. Effect of Plasma Activated Water Foliar Application on Selected Growth Parameters of Maize (Zea mays L.). Water 2020, 12, 3545. [CrossRef]

87. Kalaji, H.M.; Schansker, G.; Ladle, R.J.; Goltsev, V.; Bosa, K.; Allakhverdiev, S.I.; Brestic, M.; Bussotti, F.; Calatayud, A.; Dabrowski, P. Frequently asked questions about in vivo chlorophyll fluorescence: Practical issues. Photosynth. Res. 2014, 122, 121-158. [CrossRef]

88. Genty, B.; Briantais, J.M.; Baker, N.R. The relationship between quantum yield of photosynthetic electron transport and quenching of chlorophyll fluorescence. Biochim. Biophys. Acta 1989, 990, 87-92. [CrossRef]

89. Lichtenthaler, H.K.; Buschmann, C.; Knapp, M. How to correctly determine the different chlorophyll fluorescence parameters and the chlorophyll fluorescence decrease ratio RFd of leaves with the PAM fluorometer. Photosynthetica 2005, 43, 379-393. [CrossRef]

90. Zbíral, J. Plant Analysis: Integrated Work Procedures; Central Institute for Supervising and Testing in Agriculture: Brno, Czech Republic, 2005; p. 192. (In Czech)

91. Martinez-Feria, R.A.; Castellano, M.J.; Dietzel, R.N.; Helmers, M.J.; Liebman, M.; Huber, I.; Archontoulis, S.V. Linking cropand soil-based approaches to evaluate system nitrogen-use efficiency and tradeoffs. Agric. Ecosyst. Environ. 2018, 256, 131-143. [CrossRef]

92. Mlejnkova, V.; Horky, P.; Kominkova, M.; Skladanka, J.; Hodulikova, L.; Adam, V.; Mlcek, J.; Jurikova, T.; Sochor, J. Biogenic amines and hygienic quality of lucerne silage. Open Life Sci. 2016, 11, 280-286. [CrossRef]

93. Zhao, F.; McGrath, S.P.; Crosland, A.R. Comparison of three wet digestion methods for the determination of plant sulphur by inductively coupled plasma atomic emission spectroscopy (ICP-AES). Commun. Soil Sci. 1994, 25, 407-418. [CrossRef]

94. StatSoft, Inc. STATISTICA (Data Analysis Software System), Version 12. 2013. Available online: www.statsoft.com (accessed on 14 September 2021). 